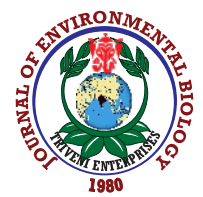

\title{
Habitat and edaphic preference of Rafflesia R. Br. plant communities in Royal Belum State Park, Perak, Peninsular Malaysia
}

\author{
A.K.N. Hayati ${ }^{1}$, K. Shamsul ${ }^{1}$, W.A.W. Juliana ${ }^{2,3}$, F.S. Mohd. Taib ${ }^{1}$, M.N. Shukor ${ }^{1}$, M.H. Shahril ${ }^{4}$ and E.A. Filza ${ }^{4}$ \\ 'Department of Biological Sciences and Biotechnology, Faculty of Science and Technology, Universiti Kebangsaan Malaysia,Bangi, 43600, \\ Malaysia \\ ${ }^{2}$ Department of Earth Sciences and Environment, Faculty of Science and Technology, Universiti Kebangsaan Malaysia, Bangi, 43600, Malaysia \\ ${ }^{3}$ Institute for Climate Change, Universiti Kebangsaan Malaysia, Bangi, 43600, Malaysia \\ ${ }^{4}$ TNB Research Sdn. Bhd., No. 1, Lorong Ayer Itam, Kawasan Institusi Penyelidikan, Kajang, 43000, Malaysia \\ *Corresponding Author Email : shamsulk@ukm.edu.my
}

\section{Abstract}

Aim: To investigate the relationship between the microhabitat conditions and soil physico-chemical characters of Rafflesia plant communities and to determine similarities across Rafflesia habitats in Royal Belum State Park, Perak, Peninsular Malaysia

Methodology: The site of Rafflesia population and its microhabitat condition was collected by referring to the previous studies, in addition to interviewing the related parties. A plot study was constructed in each Rafflesia habitat in Royal Belum State Park, Perak and the soil sample was collected for estimating their characteristics.

Results: Rafflesia population is distributed between 207 - $386 \mathrm{~m}$ asl, with the surface slope of 8 to $58^{\circ}$ and located $1.0-450.0 \mathrm{~m}$ from nearby water sources. The percentage of clay has a strong influence in X-Ray and distance to water source affected the habitat in Sg. Ruok-Papan. $\mathrm{Ca}^{2+}$ was an important soil component in Sg. Kooi while in Sg. Gadong 2 and Sg. Selantan, nitrogen was the most important soil attribute. The dendrogram reveals Sg. Kooi and Sg. Gadong 1 were the most similar habitats while Sg. Ruok differed significantly in terms of the microhabitat and soil physicochemical conditions tested.

Interpretation: This study shows that different plant communities favoured different conditions in terms of microhabitat condition and the physico-chemical characteristics of soil, despite being located within the same forest range. Since this study covered only small forest range, large sampling size which cover different forest area is needed to come to a conclusion regarding preference of Rafflesia plant communities towards its habitat.

Key words: Ecological study, Microhabitat condition, Royal Belum State Park, Soil physicochemical characters

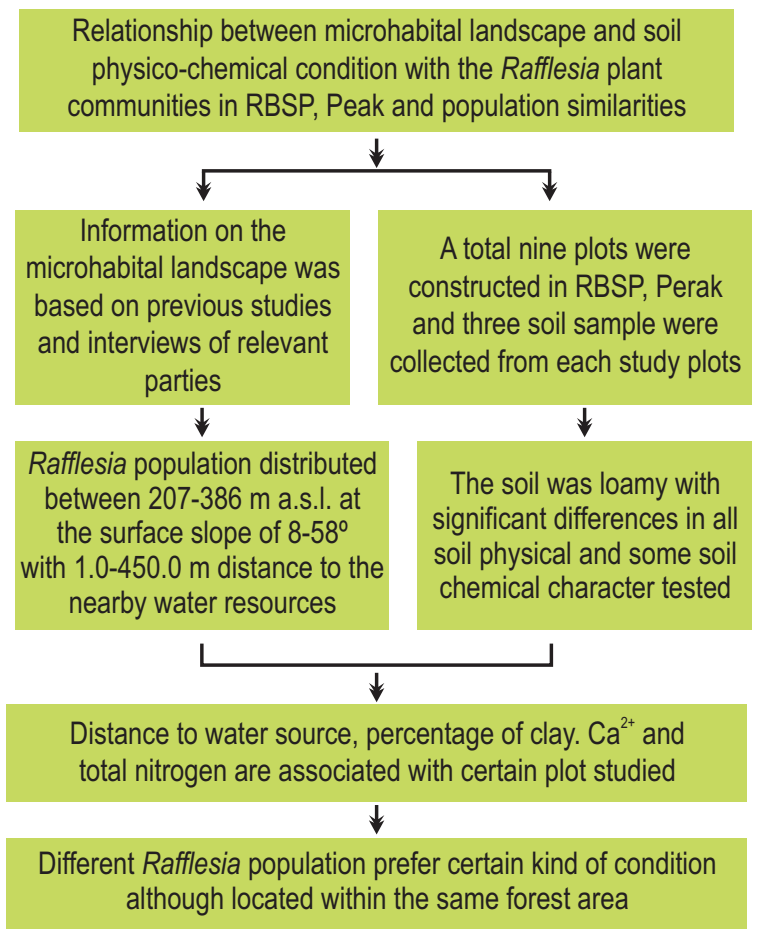

How to cite : Hayati, A.K.N., K. Shamsul, W.A.W. Juliana, F.S. Mohd Taib, M.N. Shukor, M.H. Shahril and E.A. Filza: Habitat and edaphic preference of Rafflesia R. Br. plant communities in Royal Belum State Park, Perak, Peninsular Malaysia. J. Environ. Biol., 42, 865-871 (2021). 


\section{Introduction}

Most taxonomic studies on Rafflesia sp. have been conducted in relation to identification of new species. As a holoparasitic plant, Rafflesia does not have any photosynthetic system to perform photosynthesis and produce its own food. For survival, protection and nutrient requirement Rafflesia entirely depend on its host, which is a liana, known as the Tetrastigma sp. (Nais, 2001). Due to these conditions conserving this giant flower requires conserving its habitat, especially the edaphic conditions where the host exists.

Studies have listed several factors that affect the liana growth, including its soil properties such as soil moisture content (Addo-Fordjour et al., 2014; DeWalt et al., 2006; IbarraManriquez and Martinez-Ramos, 2002; Schnitzer, 2005) and soil nutrient content (Chettri et al., 2010; DeWalt et al., 2006; Gentry, 1991; Laurance et al., 2001; Malizia et al., 2010; Swaine and Grace, 2007). Addo-Fordjour et al. (2014), DeWalt et al. (2006) and Ibarra-Manriquez and Martinez-Ramos (2002) discovered that the liana diversity, species richness and abundance increased proportionally with the soil moisture content. However, this result is contradictory to Schnitzer (2005). In terms of nutrient content, Malizia et al. (2010) found that the liana abundance was increased with the phosphorus content. The soil $\mathrm{pH}$ and magnesium content were found to influence the basal area and diameter of the liana (Addo-Fordjour et al., 2014). While Homeier et al. (2010) stated that the available nitrogen affects the liana abundance, and there was a positive effect on the exchangeable calcium and negative effect on the exchangeable aluminium towards the liana density.

However, this knowledge cannot be solely accepted since this information focuse on lianas in general, which have habitats and communities that differ from the Rafflesia plant communities. To date, only Pranata et al. (2019) has studied specifically on Rafflesia plant communities in relation to soil condition. Nevertheless, this information is insufficient to conclude the specific edaphic condition that becomes the preference for Rafflesia plant communities.

This information is crucial especially given that the Rafflesia habitat attracts significant tourist numbers which threatens to disturb its growth. This situation can be seen in Royal Belum State Park, Perak, Peninsular Malaysia which serves as home to three Rafflesia species, namely Rafflesia cantleyi, $R$. kerrii and $R$. azlanii. Due to ecotourism, the population and distribution of Rafflesia has decreased due to human interruption, and natural disturbances of course (Farah Khaliz et al., 2018; Nasihah et al., 2016).

To date, only a handful of studies have been conducted on Rafflesia within the Royal Belum State Park which focus on the distribution (Farah Khaliz et al., 2018; Nur Hayati et al., 2020) and physiology (Farah Khaliz et al., 2018). Unfortunately, no study has so far focused on the relationship between the host and its soil condition. Since soil provides nutrients required by the majority of vegetation for their survival, this study is crucial to conserve the Rafflesia population in Royal Belum State Park. Therefore, this study was conducted to determine the relationship between the Rafflesia plant communities with the microhabitat condition and edaphic factors within the Rafflesia habitat in Royal Belum State Park.

\section{Materials and Methods}

Study area : The study area is one of the most popular ecotourism sites in Peninsular Malaysia located at the upper part of Belum-Temengor Forest Complex. Royal Belum State Park covers approximately $90 \%$ of the Belum-Temengor Forest Reserve, covering total area of 117,500 ha. Nine Rafflesia populations have been recorded in Royal Belum State Park, and a total plot area of 1.13 ha plot has been constructed. The plot covers the Rafflesia population in the following sites: Sg. Gadung 1 (SG1), Sg. Gadung 2 (SG2), X-Ray (XR), Sg. Ruok (SR), Sg. Ruok-Papan (SRP), Sg. Kooi (SK), Sg, Kenarong (SKG), Sg. Tiang (ST) and Sg. Selatan (SS).

Microhabitat condition: This study included information pertaining to altitude, slope degree and distance of the population to nearby water resources. This information was based on Nur Hayati et al. (2020) with additional information gathered by interviewing the communities in Royal Belum State Park.

Plot set-up and soil collection: A circular-shaped plot of $5 \mathrm{~m}$ radius was constructed from the host in each Rafflesia population in Royal Belum State Park. Three replicates of soil samples were then collected with a soil auger with $20 \mathrm{~cm}$ depth in each study plot. The soil samples were later stored in plastic bags and secured tightly.

Soil analysis: The soil physical properties included the soil texture, water content and the organic matter content. Physical classification of soils using soil texture triangles (USDA, 1960). Soil water content was measured by subtracting the weight of the dry soil from the weight of the moist soil, and then dividing by the weight of the dry soil. While to estimate the amount organic matter present in a soil sample is by measuring the weight lost by an oven-dried $\left(105^{\circ} \mathrm{C}\right)$ soil sample when it is heated to $400^{\circ} \mathrm{C}$; this is known as 'loss on ignition', essentially the organic matter is burnt off(Avery and Bascomb,1982).

The parameters for the chemical properties analyses including the soil $\mathrm{pH}$, electrical conductivity (EC), cation exchange capacity (CEC) and available nutrients were measured. The $\mathrm{pH}$ of the soil was tested using 1:2.5 soil to water ratio (Metson, 1956), while the soil EC was measured using a conductivity metre. In determining CEC, the sample was 
analysed using the summation method through ICP-MS (Inductively Coupled Plasma-Mass Spectrophotometer) machine. For the available nutrients of phosphorus, it was determined through the available methods and tested using Ultraviolet (UV) Spectrophotometer, while potassium, magnesium and calcium were determined through ICP-MS.

Data analyses: The collected samples were analyzed for major physical and chemical soil quality parameter like soil $\mathrm{pH}$, electricalconductivity (EC), organic carbon (OC), available nitrogen $(\mathrm{N})$, phosphorus $(\mathrm{P})$, potassium $(\mathrm{K})$. One-way ANOVA of IBM SPSS Statistics version 22 were used for analyzingthe physical and chemical soil data, while Principal Canonical Analysis (PCA)and Cluster Analyses were conducted using PaleontoligalStatistic (PAST) version 2.14 to ascertain the preference of hostregarding topography and soil elements tested.

\section{Results and Discussion}

The study is a continuation of Nur Hayati et al. (2020) which this study describes the microhabitat, and physical and chemical characteristics of the soil. Data were added regarding the distance of the host tothe nearby water source for Sg. Kooi and Sg. Kenarong. Table 1 shows complete information regarding the microhabitat conditions of Rafflesia populations in Royal Belum State Park, Perak.

Through this study, the Rafflesia plant communities in Royal Belum State Park were found to grow above $207 \mathrm{~m}$ a.s.l. with the maximum slope angle of $58^{\circ}$. The farthest distance of the host to the water source was $450.0 \mathrm{~m}$ in Sg. Kenarong. However, Nasihah et al. (2016) in Lojing Highlands, Kelantan and Pranata et al. (2019) in Padam Gadang, West Sumatra, reported that the Rafflesia population existed at much higher elevations of 800 $1200 \mathrm{~m}$ a.s.l. and 800-1024 m a.sl., respectively. However, this range depended on the Rafflesia species existing within that particular area (Nais, 2001). While in terms of distance to the water source, this study showed a quite high range of Rafflesia population distance to its nearby water source when compared to Pranata et al. (2019) who stated that Rafflesia population in Padam Gadang, West Sumatra ranged between 3.0-27.8 m from the water source.

The Rafflesia habitat in the Royal Belum State Park is mainly characterised by loam soil which is able to retain more nutrients and humus, and has better infiltration and drainage compared to clay soils (Osman, 2013). Most tree species grow well in sandy loam to clay loam texture due to adequate supply water, air, and nutrients. About three out of nine Rafflesia habitats $(33.33 \%)$ were represented with loam soil texture, two habitats with sandy clay loam $(22.22 \%)$, and one habitat with silty clay loam $(11.11 \%)$, clay loam (11.11\%), sandy loam (11.11\%) and clay (11.11\%) (Table 2). This study is similar to Nasihah et al. (2016) except that there is a percentage difference for each soil texture.
The soil texture of Royal Belum State Park was largely dominated by the sandy texture (17.94 to $69.76 \%$ ), followed by silt (14.93 to $42.10 \%$ ) and clay (15.31 to $47.78 \%$ ), respectively (Table 2) with significant figures for all these soil textures among the studied plots $(p<0.05)$.

The average percentage of organic matter content of the study ranged from low $(2.30 \%)$ to medium $(8.17 \%) \quad(p=0.004)$ (Table 2). Landon (1991) and Sharu et al. (2013) stated that $4 \%$ to $10 \%$ of organic matter content is considered as average. However, it was quite high compared to that reported by Nasihah et al. (2016) in Lojing Highland, Kelantan with organic content ranging from $2.36 \%$ to $4.19 \%$.

Table 2 shows that the soil moisture content within the study area ranged from $3.81 \%$ to $7.13 \%$. The highest soil humidity content was found in the habitat of Rafflesia in Sg. Selatan characterised by clay-soil type, followed by Sg. Ruok-Papan with clay loam texture. This could be a certained to the property of clay that has little space which enable the soil to retain more water compared to other soil textures (Othman, 2013).

The soil chemical properties of nine study plots is shown in Table 3. According to McCauley et al. (2017), the pH value of forest soil is in the range of 3-5, whereas Othman and Shamshuddin (1982) reported that the typical $\mathrm{pH}$ value of tropical rainforest in Peninsular Malaysia is between 4.5-5.5. Both statements showed that forested area, especially in Peninsular Malaysia exists in acidic soil condition. This condition is in line with the soil pH of nine study plots at Royal Belum State Park, with the average values ranging between 3.51 to 4.29 . Furthermore, the $\mathrm{pH}$ value showed significant difference $(\mathrm{p} \leq 0.01)$ between the sites. Pranata et al. (2019) reported that the Rafflesia population in Padam Gadang, West Sumatra, had a much higher $\mathrm{pH}$ value, ranging from 7.0-7.8. This difference might be due to different environmental conditions which affecs the soil composition since it is located at high elevations in West Sumatra.

The electrical conductivity within the nine Rafflesia habitats in Royal Belum State Park ranged from 1.85 to 2.47 (Table 3). Referring to Schoeneberger et al. (2002), these values were within the range of non-saline $\left(<2 \mathrm{mS} \mathrm{cm}^{-1}\right)$ to mild saline (2 to less than $4 \mathrm{mS} \mathrm{cm}^{-1}$ ). According to Shamshuddin (1981), a higher index of electrical conductivity may disturb the development and growth of plants. Smith and Doran (1996) suggested that $E C$ value ranging from 0 to $1 \mathrm{mS} \mathrm{cm}^{-1}$ indicates good soil health, while if the range is above than 1 to $2 \mathrm{mS} \mathrm{cm}^{-1}$, it will reduce the growth of salt-sensitive plants and disrupt the microbially mediated processes of nitrification and denitrification. They also stated that cation in solution is always balanced with the cation in soil particles. Cation in the solution can be taken up by the roots through osmosis. The nutrient will be lost slowly but will be replaced by the minerals from other sources. To achieve the electrical balance, the cation is adsorbed by the clay minerals 
Table 1: Microhabitat conditions of Rafflesia's host in the Royal Belum State Park, Perak

\begin{tabular}{llll}
\hline Sites & Elevation (a.s.l.) & Slope $\left(^{\circ}\right)$ & Distance to water source $(\mathrm{m})$ \\
\hline Sg. Gadong 1 & 291 & 40 & 13.0 \\
Sg. Gadong 2 & 386 & 50 & 11.5 \\
Sg. Ruok-Papan & 237 & 24 & 6.4 \\
Sg. Ruok & 207 & 8 & 1.0 \\
Sg. Tiang & 347 & 38 & 9.9 \\
Sg. Kooi & 360 & 58 & 20.0 \\
Sg. Kenarong & 295 & 8 & 450.0 \\
X-Ray & 270 & 56 & 9.0 \\
Sg. Selantan & 363 & 46 & 40.0 \\
\hline
\end{tabular}

Table 2: A total of mean $( \pm S D)$ soil characteristics in study sites

\begin{tabular}{|c|c|c|c|c|c|c|}
\hline Sites & Sand $(\%)$ & Silt (\%) & Clay (\%) & Soil texture & Organic matter (\%) & Soil moisture (\%) \\
\hline Sg. Gadong 1 & $17.94 \pm 1.00^{\circ}$ & $42.10 \pm 2.88^{\mathrm{a}}$ & $39.96 \pm 3.02^{\mathrm{ab}}$ & Silty clay loam & $4.60 \pm 0.42^{\mathrm{abc}}$ & $5.11 \pm 0.84^{\mathrm{bc}}$ \\
\hline Sg. Gadong 2 & $45.83 \pm 3.50^{\text {bc }}$ & $33.23 \pm 1.47^{\text {bc }}$ & $20.94 \pm 2.05^{\text {cd }}$ & Loam & $8.17 \pm 4.30^{\mathrm{a}}$ & $5.14 \pm 0.56^{b c}$ \\
\hline Sg. Ruok-Papan & $41.73 \pm 3.91^{\circ}$ & $24.11 \pm 0.47^{\mathrm{de}}$ & $34.16 \pm 3.49^{b}$ & clay loam & $4.32 \pm 0.78^{\mathrm{abc}}$ & $6.17 \pm 1.09^{\mathrm{ab}}$ \\
\hline Sg. Ruok & $69.76 \pm 1.95^{\mathrm{a}}$ & $14.93 \pm 0.87^{f}$ & $15.31 \pm 1.16^{d}$ & Sandy loam & $2.83 \pm 0.52^{\mathrm{bc}}$ & $3.81 \pm 0.30^{\circ}$ \\
\hline Sg. Tiang & $51.50 \pm 4.61^{b}$ & $25.13 \pm 0.82^{d}$ & $23.38 \pm 4.48^{\text {cd }}$ & Sandy clay loam & $2.30 \pm 0.19^{c}$ & $4.50 \pm 0.40^{\mathrm{bc}}$ \\
\hline Sg. Kooi & $60.91 \pm 1.78^{\mathrm{a}}$ & $14.97 \pm 0.29^{f}$ & $24.12 \pm 1.50^{\circ}$ & Sandy clay loam & $6.93 \pm 0.59^{\mathrm{ab}}$ & $5.16 \pm 0.25^{\mathrm{bc}}$ \\
\hline Sg. Kenarong & $44.20 \pm 2.43^{\mathrm{bc}}$ & $31.15 \pm 0.87^{\circ}$ & $24.65 \pm 1.56^{c}$ & Loam & $4.93 \pm 0.43^{\mathrm{abc}}$ & $5.33 \pm 1.02^{\mathrm{abc}}$ \\
\hline X-Ray & $38.22 \pm 2.42^{\text {cd }}$ & $36.67 \pm 0.65^{b}$ & $25.11 \pm 2.03^{c}$ & Loam & $4.08 \pm 0.57^{\mathrm{abc}}$ & $5.66 \pm 0.59^{\mathrm{abc}}$ \\
\hline Sg. Selantan & $31.62 \pm 5.66^{d}$ & $20.59 \pm 0.86^{\circ}$ & $47.78 \pm 5.00^{\mathrm{a}}$ & Clay & $5.81 \pm 0.45^{\mathrm{abc}}$ & $7.13 \pm 0.50^{\mathrm{a}}$ \\
\hline$p$-value & $9.82 \times 10^{-12}$ & $2.39 \times 10^{-15}$ & $1.96 \times 10^{-9}$ & - & $3.68 \times 10^{-3}$ & $9.17 \times 10^{-4}$ \\
\hline
\end{tabular}

Values with similar alphabet are not significantly different with $p>0.05$ based on Tukey HSD t.

(Othman and Shamshuddin, 1982).

Cation exchange capacity is an important soil chemical property. It as it describes soil fertility, nutrient-holding capacity and the ability to control groundwater from cation contamination (Khairil et al., 2014). The average value of CEC of soil of study

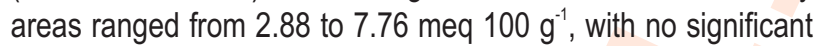
difference between sites ( $p>0.05)$. According to Esu (1991) and Sharu et al. (2013), the CEC values recorded were considered low to medium. In addition, Shamshuddin (1981) suggested that tropical soil requires an effective CEC of $>4$ meq $100 \mathrm{~g}^{-1}$ which is possible due to high weathering conditions.

According Othman and Shamsuddin (1982) stated that tropical soils vary greatly in their principal chemical and physical properties, such as parent material, soil structure, drainage regime, and age. Variations in soil properties play an important role in the different types of tropical forest ecosystems. The plants require macronutrients for growth and without sufficient supply of these nutrients, the plant cannot grow well or may die. Table 3 shows that most of the study plots had the highest potassium content compared to other available macronutrients. The highest value $\left(5347.14 \mu \mathrm{g} \mathrm{g}^{-1}\right)$ was recorded in $\mathrm{Sg}$. Tiang. This result was very high compared to Nasihah et al. (2016) who found that the available potassium content within their study areas ranged between $0.11 \mu \mathrm{g} \mathrm{g}^{-1}$ to $0.26 \mu \mathrm{g} \mathrm{g}^{-1}$. However, the results showed no significant difference $(p>0.05)$ in this available macronutrient across the study plots at Royal Belum State Park.

The highest mean value of phosphorus $\left(5.71 \mu \mathrm{g} \mathrm{g} \mathrm{g}^{-1}\right)$ reported in Sg. Kooi while the lowest average value was recorded in X-Ray $\left(1.15 \mu \mathrm{g} \mathrm{g}^{-1}\right)$. Although the gap between the highest and lowest mean values for phosphorus content was only $4.56 \mathrm{\mu g} \mathrm{g}^{-1}$, One-way ANOVA analysis showed that there was a very significant difference between the study plots $(p \leq 0.001)$ (Table 3). Previous studies have reported different ranges for phosphorus content. Several factors affect the phosphorus concentration in soil, including the adsorption and absorption processes by plants, use of fertilisers and decomposition of inorganic phosphorus (Frossard et al., 2000). Friesen et al. (1980) also stated that the pH value of soil also affects phosphorus content, where the increase in $\mathrm{pH}$ values will reduce phosphorus content. In addition, organic matter content also affects the macronutrient values of soil (Othman and Shamshuddin, 1982).

The results showed the highest magnesium level was found in soil samples of Sg. Ruok, while the lowest was observed in Sg. Ruok-Papan (Table 3). There were also significant differences $(p<0.05)$ in $\mathrm{Mg}$ content between the plots. 
Table 3 : Soil chemical properties of nine study plots and the $p$-value based on One-way ANOVAat RBSP, Perak

\begin{tabular}{|c|c|c|c|c|c|c|c|c|c|c|}
\hline Parameter & SG1 & SG 2 & SRP & SR & ST & SK & SKG & $\mathrm{XR}$ & SS & $p$-value \\
\hline $\begin{array}{l}\mathrm{pH} \\
\mathrm{EC} \\
\left(\mathrm{mS} \mathrm{cm}^{-1}\right)\end{array}$ & $\begin{array}{l}3.51 \pm 0.03^{\mathrm{c}} \\
2.40 \pm 0.09^{\mathrm{ab}}\end{array}$ & $\begin{array}{l}3.59 \pm 0.16^{\mathrm{bc}} \\
2.47 \pm 0.12^{\mathrm{a}}\end{array}$ & $\begin{array}{l}3.53 \pm 0.05^{c} \\
2.26 \pm 0.03^{\text {bc }}\end{array}$ & $\begin{array}{l}3.68 \pm 0.06^{b c} \\
2.23 \pm 0.07^{b c}\end{array}$ & $\begin{array}{l}3.60 \pm 0.21^{b c} \\
2.25 \pm 0.02^{b c}\end{array}$ & $\begin{array}{l}3.73 \pm 0.10^{\mathrm{bc}} \\
2.45 \pm 0.05^{\mathrm{a}}\end{array}$ & $\begin{array}{l}4.29 \pm 0.12^{\mathrm{a}} \\
2.38 \pm 0.02^{\mathrm{ab}}\end{array}$ & $\begin{array}{l}3.88 \pm 0.10^{b} \\
2.16 \pm 0.02^{c}\end{array}$ & $\begin{array}{l}3.76 \pm 0.10^{b c} \\
1.85 \pm 0.08^{d}\end{array}$ & $\begin{array}{l}5.58 \times 10^{-6} \\
1.92 \times 10^{-8}\end{array}$ \\
\hline \multicolumn{11}{|c|}{ Exchangeable cation (meq $100 \mathrm{~g}^{-1}$ ) } \\
\hline $\mathrm{Ca}^{2+}$ & $0.22 \pm 0.02^{\mathrm{bcd}}$ & $0.42 \pm 0.25^{\mathrm{bc}}$ & $0.11 \pm 0.11^{d}$ & $0.19 \pm 0.01^{\text {cd }}$ & $0.22 \pm 0.09^{\text {bcd }}$ & $0.49 \pm 0.03^{b}$ & $0.91 \pm 0.08^{\mathrm{a}}$ & $0.47 \pm 0.08^{\text {bc }}$ & $0.25 \pm 0.04^{\mathrm{bcd}}$ & $8.99 \times 10^{-7}$ \\
\hline $\mathrm{Mg}^{2+}$ & $0.32 \pm 0.20^{\mathrm{bc}}$ & $0.72 \pm 0.48^{\mathrm{ab}}$ & $0.05 \pm 0.05^{c}$ & $0.21 \pm 0.07^{\mathrm{bc}}$ & $0.12 \pm 0.02^{\mathrm{bc}}$ & $0.53 \pm 0.20^{\mathrm{bc}}$ & $1.22 \pm 0.17^{\mathrm{a}}$ & $1.26 \pm 0.25^{\mathrm{a}}$ & $0.52 \pm 0.10^{\mathrm{bc}}$ & $4.88 \times 10^{-6}$ \\
\hline $\mathrm{Na}^{+}$ & $0.62 \pm 0.06^{a}$ & $0.61 \pm 0.02^{\mathrm{a}}$ & $0.37 \pm 0.38^{\mathrm{a}}$ & $0.82 \pm 0.14^{\mathrm{a}}$ & $1.79 \pm 1.83^{\mathrm{a}}$ & $0.62 \pm 0.02^{\mathrm{a}}$ & $0.70 \pm 0.09^{\mathrm{a}}$ & $0.61 \pm 0.01^{\mathrm{a}}$ & $0.61 \pm 0.01^{\mathrm{a}}$ & $3.17 \times 10^{-1}$ \\
\hline $\mathrm{K}^{+}$ & $1.29 \pm 0.35^{\mathrm{a}}$ & $1.63 \pm 0.59^{\mathrm{a}}$ & $0.38 \pm 0.35^{\mathrm{a}}$ & $0.86 \pm 0.24^{\mathrm{a}}$ & $4.23 \pm 5.61^{\mathrm{a}}$ & $2.00 \pm 0.36^{a}$ & $0.91 \pm 0.01^{\mathrm{a}}$ & $1.10 \pm 0.04^{a}$ & $1.00 \pm 0.05^{\mathrm{a}}$ & $4.28 \times 10^{-1}$ \\
\hline $\mathrm{Al}^{3+}$ & $4.10 \pm 0.60^{\mathrm{a}}$ & $1.43 \pm 0.60^{b}$ & $1.33 \pm 0.40^{b}$ & $0.83 \pm 0.21^{\mathrm{bc}}$ & $1.00 \pm 0.17^{\mathrm{bc}}$ & $0.83 \pm 0.12^{\mathrm{bc}}$ & $0.17 \pm 0.06^{c}$ & $0.93 \pm 0.42^{\text {bc }}$ & $1.37 \pm 0.12^{b}$ & $1.10 \times 10^{-8}$ \\
\hline $\mathrm{H}^{+}$ & $0.50 \pm 0.10^{\mathrm{a}}$ & $0.50 \pm 0.40^{\mathrm{a}}$ & $0.63 \pm 0.25^{\mathrm{a}}$ & $0.37 \pm 0.06^{a}$ & $0.40 \pm 0.26^{a}$ & $0.33 \pm 0.06^{a}$ & $0.27 \pm 0.06^{\mathrm{a}}$ & $0.37 \pm 0.06^{a}$ & $0.50 \pm 0.17^{\mathrm{a}}$ & $4.80 \times 10^{-1}$ \\
\hline CEC & $7.06 \pm 0.42^{\mathrm{a}}$ & $5.31 \pm 0.30^{\mathrm{a}}$ & $2.88 \pm 0.80^{\mathrm{a}}$ & $3.28 \pm 0.35^{\mathrm{a}}$ & $7.76 \pm 7.41^{\mathrm{a}}$ & $4.80 \pm 0.23^{\mathrm{a}}$ & $4.18 \pm 0.17^{\mathrm{a}}$ & $4.74 \pm 0.16^{\mathrm{a}}$ & $4.24 \pm 0.04^{\mathrm{a}}$ & $3.30 \times 10^{-1}$ \\
\hline \multicolumn{11}{|c|}{ Available nutrients $\left(\mu \mathrm{g} \mathrm{g}^{-1}\right)$} \\
\hline $\mathbf{N}$ & $0.57 \pm 0.11^{\mathrm{abc}}$ & $0.59 \pm 0.19^{\mathrm{ab}}$ & $0.61 \pm 0.11^{\mathrm{ab}}$ & $0.20 \pm 0.06^{\mathrm{c}}$ & $0.28 \pm 0.13^{\mathrm{bc}}$ & $0.62 \pm 0.04^{\mathrm{ab}}$ & $0.19 \pm 0.03^{c}$ & $0.68 \pm 0.26^{a}$ & $0.63 \pm 0.07^{\mathrm{ab}}$ & $3.90 \times 10^{-4}$ \\
\hline P & $1.97 \pm 0.25^{\text {bc }}$ & $3.85 \pm 1.65^{\mathrm{ab}}$ & $2.40 \pm 0.15^{b c}$ & $2.14 \pm 0.57^{\text {bc }}$ & $2.40 \pm 0.11^{\mathrm{bc}}$ & $5.71 \pm 0.70^{\mathrm{a}}$ & $2.60 \pm 0.67^{\text {bc }}$ & $1.15 \pm 0.48^{c}$ & $3.27 \pm 0.70^{b}$ & $3.319 \times 10^{-5}$ \\
\hline K & $\begin{array}{l}496.31 \\
\pm 395.53^{\mathrm{a}}\end{array}$ & $\begin{array}{l}344.40 \\
\pm 137.84^{\mathrm{a}}\end{array}$ & $\begin{array}{l}116.25 \\
\pm 6.30^{\mathrm{a}}\end{array}$ & $\begin{array}{l}131.90 \\
\pm 27.40^{\mathrm{a}}\end{array}$ & $\begin{array}{l}5347.14 \\
\pm 8889.55^{a}\end{array}$ & $\begin{array}{l}479.35 \\
\pm 168.29^{\mathrm{a}}\end{array}$ & $\begin{array}{l}186.85 \\
\pm 5.39^{\mathrm{a}}\end{array}$ & $\begin{array}{l}230.51 \\
\pm 17.55^{\mathrm{a}}\end{array}$ & $\begin{array}{l}193.30 \\
\pm 12.35^{\mathrm{a}}\end{array}$ & $6.43 \times 10^{-1}$ \\
\hline Mg & $\begin{array}{l}93.25 \\
\pm 42.05^{\mathrm{a}}\end{array}$ & $\begin{array}{l}200.55 \\
\pm 113.61^{\mathrm{a}}\end{array}$ & $\begin{array}{l}34.35 \\
\pm 12.23^{\mathrm{a}}\end{array}$ & $\begin{array}{l}1085.84 \\
\pm 1763.05^{\mathrm{a}}\end{array}$ & $\begin{array}{l}502.49 \\
\pm 798.12^{\mathrm{a}}\end{array}$ & $\begin{array}{l}127.66 \\
\pm 28.08^{\mathrm{a}}\end{array}$ & $\begin{array}{l}321.93 \\
\pm 26.22^{\mathrm{a}}\end{array}$ & $\begin{array}{l}292.42 \\
\pm 59.56^{\mathrm{a}}\end{array}$ & $\begin{array}{l}117.03 \\
\pm 21.91^{\mathrm{a}}\end{array}$ & $4.81 \times 10^{-1}$ \\
\hline $\mathrm{Ca}$ & $\begin{array}{l}60.33 \\
\pm 14.99^{\mathrm{a}}\end{array}$ & $\begin{array}{l}117.42 \\
\pm 80.23^{\mathrm{a}}\end{array}$ & $\begin{array}{l}53.23 \\
\pm 15.05^{\mathrm{a}}\end{array}$ & $\begin{array}{l}3053.45 \\
\pm 5174.34^{\mathrm{a}}\end{array}$ & $\begin{array}{l}69.59 \\
\pm 11.40^{\mathrm{a}}\end{array}$ & $\begin{array}{l}143.94 \\
\pm 29.30^{\mathrm{a}}\end{array}$ & $\begin{array}{l}237.15 \\
\pm 9.84^{\mathrm{a}}\end{array}$ & $\begin{array}{l}113.58 \\
\pm 29.03^{\mathrm{a}}\end{array}$ & $57.79 \pm 4.53^{\mathrm{a}}$ & $4.85 \times 10^{-1}$ \\
\hline
\end{tabular}

Values are mean $\pm S D$; Values with similar alphabet were not significantly different with $p>0.05$ based on Tukey HSD test. EC $=$ electrical conductivity, $\mathrm{Ca}^{2+}=$ exchangeable calcium, $\mathrm{Mg}^{2+}=$ exchangeable magnesium, $\mathrm{Na}^{+}=$exchangeable sodium, $\mathrm{K}^{+}=$exchangeable potassium, $\mathrm{Al}^{3+}=$ exchangeable aluminium, $\mathrm{H}^{+}=$exchangeable hydrogen, $\mathrm{CEC}=$ cation exchange capacity, $\mathrm{N}=$ nitrogen, $\mathrm{P}=$ phosphorus, $\mathrm{K}=$ potassium, $\mathrm{Mg}=\mathrm{Magnesium}, \mathrm{Ca}=$ Calcium, SG 1 = Sg. Gadong 1, SG 2 = Sg. Gadong 2, SRP = Sg. Ruok-Papan, SR = Sg. Ruok, ST = Sg. Tiang, SK= Sg. Kooi, SKG= Sg. Kenarong, XR= X-Ray, SS = Sg. Selantan

Furthermore, the Ca content between the plots ranged between 53.23 to $3053.45 \mu g^{-1}$ that showed no significant differences ( $p$ > 0.05 ) between the study plots (Table 3 ).

Fig. 2 shows three distinct groups based on the physical properties studied. The first group located in positive PC-1 and PC-2 showed that $\mathrm{Sg}$. Gadong 2 was associated with the elevation, slope and soil organic content. The second group in positive PC-1 and negative PC-2 revealed soil moisture, percentage of silt and clay, and distance of the host to water source does affect X-Ray, Sg. Gadong 1, Sg. Ruok-Papan and Sg. Kenarong. While third group in positive PC-2 showed Sg. Tiang has a relationship with the percentage of the sand. This third group supported by Nasihah et al. (2016) found the percentage of sand directly affected the Tetrastigma sp. in Lojing Highland, Kelantan. Since no similar pattern in the plot distribution in relation to soil physical factors was observed, it shows that different populations were associated with certain soil physical conditions despite being located within the same forest area.

There was an unclear grouping between the soil chemical characters with the plots (Fig. 3). The PCA ordination shows that Sg. Kooi was highly correlated with exchangeable calcium and $\mathrm{pH}$. This result is similar to Nasihah et al. (2016) who stated that the soil pH affected the Tetrastigma sp. and R. kerrii in Kelantan. This study also found that Sg. Gadong 2 and $\mathrm{Sg}$. Selantan were associated with total soil nitrogen while $\mathrm{Sg}$. Gadong 1 related to exchangeable aluminium $\left(\mathrm{Al}^{3+}\right)$ and hydrogen $\left(\mathrm{H}^{+}\right)$. These results were similar to the soil physical characteristics which showed that each population had an exclusive preference for soil characteristics.

Cluster analysis was performed to test the similarity between Rafflesia habitats in terms of microhabitat condition and soil physico-chemical characteristics. The analysis indicated that habitat Sg. Kooi and Sg. Gadong 1 showed the highest similarity, followed by Sg. Ruok-Papan and Sg. Selantan (Fig. 4). Only threephysical characters (soil moisture, sand and organic matter) and one chemical $\left(\mathrm{Mg}^{2+}\right)$ character of soil weresignificantly different $(p<0.05)$ for Sg. Kooi and Sg. Gadong 1. Additionally, soil moisture, EC, exchangeable $\mathrm{Na}^{+}$and $\mathrm{Mg}^{2+}$ and available $\mathrm{P}$ were same between $\mathrm{Sg}$. Kooi and Sg. Gadong.

Sg. Ruok showed the least habitat similarity compared to other Rafflesia habitat in this study. Sg. Ruok recorded the lowest elevation level and slope angle, and its location was nearest to the water source as compared to other study plots in Royal Belum State Park. Sg. Ruok also recorded the highest percentage of sand but the lowest for clay and soil moisture, in addition to lower 


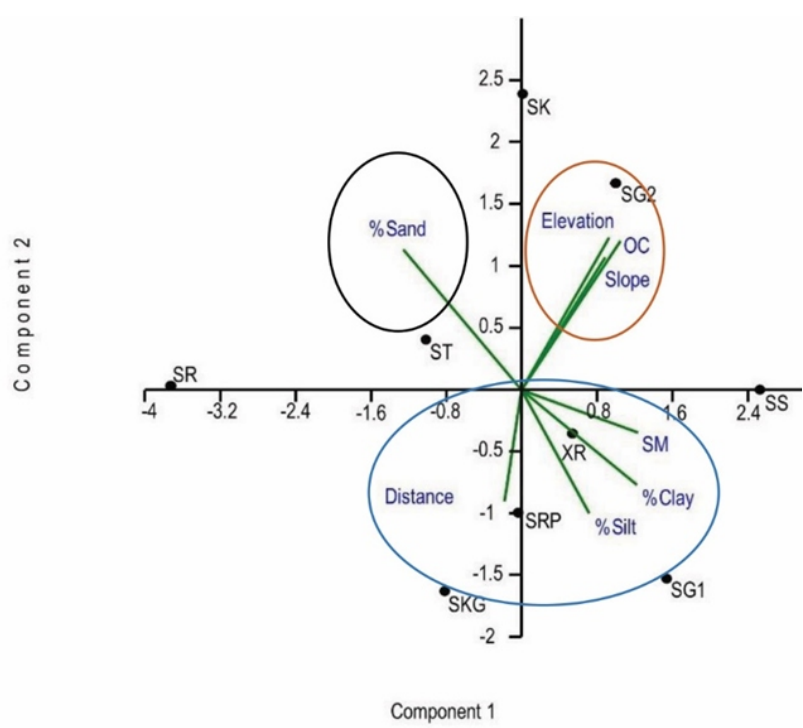

Fig. 2: PCA ordination of microhabitat condition and soil physical characters in the habitat of Rafflesia host in RBSP, Perak (Note: Slope = Slope angle, Distance $=$ Distance to the water source,$S M=$ soil moisture, $\mathrm{OC}=$ organic content, $\mathrm{SG1}=\mathrm{Sg}$. Gadong 1, SS = Sg. Selantan, XR = Xray, $\mathrm{SRP}=$ Sg. Ruok-Papan, $S K G=$ Sg. Kenarong, $S G 2=$ Sg. Gadong 2, ST $=$ Sg. Tiang, $S K=$ Sg. Kooi, SR = Sg. Ruok).

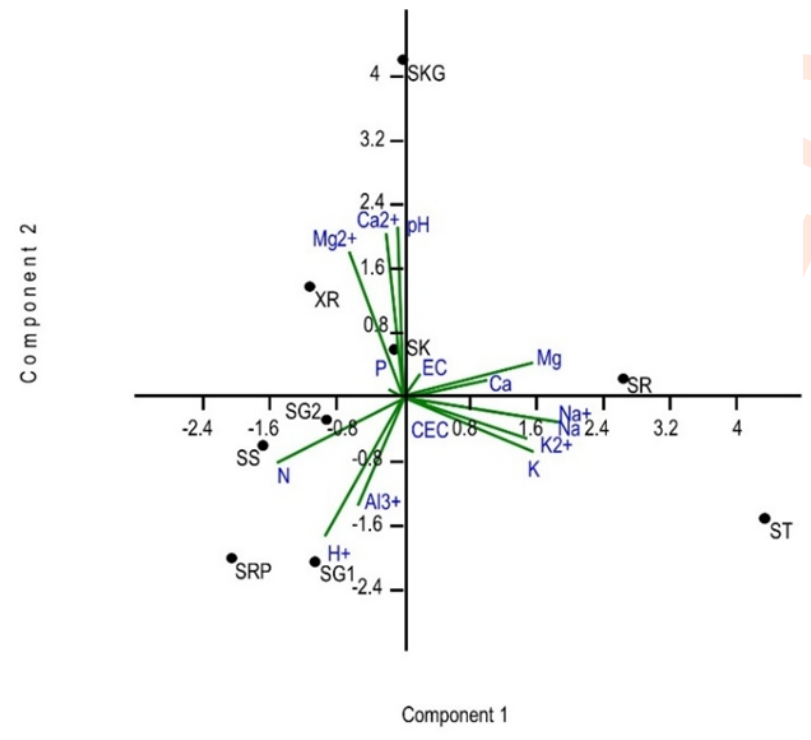

Fig. 3: PCA ordination of soil chemical characters in the habitat of Rafflesia host in RBSP, Perak ( EC = electrical conductivity, $\mathrm{N}=$ nitrogen, $\mathrm{P}=$ phosphorus, $\mathrm{K}=$ potassium, $\mathrm{Mg}=$ Magnesium, $\mathrm{Ca}=$ Calcium, $\mathrm{Ca}^{2+}=$ exchangeable calcium, $\mathrm{Mg}^{2+}=$ exchangeable magnesium, $\mathrm{Na}^{+}=$ exchangeable sodium, $\mathrm{K}^{+}=$exchangeable potassium, $\mathrm{Al}^{3+}=$ exchangeable aluminium, $\mathrm{H}^{+}=$exchangeable hydrogen, $\mathrm{CEC}=$ cation exchanged capacity, $S R=S g$. Ruok, $S K G=S g$. Kenarong, $X R=X$-ray, SG2 = Sg. Gadong 2, SS = Sg. Selantan, SRP = Sg. Ruok-Papan, $S K=$ Sg. Kooi, SG1 = Sg. Gadong 1, ST = Sg. Tiang).

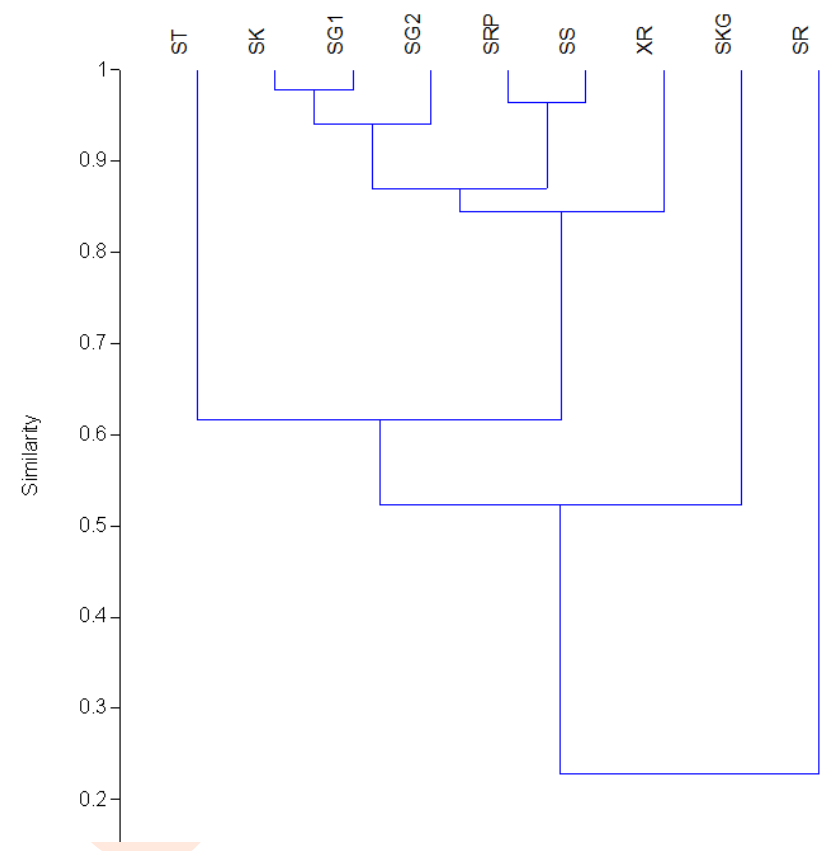

Fig. 4 : Habitat similarity based on the correlation cluster analysis for Rafflesia population in RBSP, Perak (ST = Sg. Tiang, SK = Sg. Kooi, SG1 = Sg. Gadong 1, SG2 = Sg. Gadong 2, SRP = Sg. Ruok-Papan, SS = Sg. Selantan, $\mathrm{XR}=\mathrm{X}$-ray, $\mathrm{SKG}=\mathrm{Sg}$. Kenarong, $\mathrm{SR}=\mathrm{Sg}$. Ruok).

organic content. This indicates that Sg. Ruok was the least fertile plot as high sand, and low clay content caused water to leach easily, and fewer nutrients were stored. In terms of soil chemical characters, Sg. Ruok also recorded a low nitrogen content but had the highest magnesium and calcium content compared to others.

This study reveals that the Rafflesia population in Royal Belum State Park prevail existed in the slope area of the lowland forests, mostly located close to water resources. It was also found that the Rafflesia population grew in loamy soil in acidic condition and medium soil organic content. The analysis revealed that different plant communities favoured different microhabitat and soil physico-chemical conditions, even though located within the same forest range. This condition does lead to the aggregation of Rafflesia population in Royal Belum State Park, Perak for habitat similarity analysis.

\section{Acknowledgments}

This work was funded by research grant ST-2017-009 and collaboration with TNB Research and Perbadanan Taman Negeri Perak (PTNPk). We would like to thank Prof. Dr. Shukor Md. Nor as the project leader, Prof. Emeritus Dato' Dr. Abdul Latiff Mohamad for his advice and suggestions, En. Azman Hashim, Norazlinda Mohamad and Muhammad Izzat-Husna for their help while conducting this study. 


\section{Add-on Information}

Authors' contribution : A.K.N. Hayati: Graduate Research Assistant; K. Shamsul: Main supervisor; W.A.W. Juliana: Cosupervisor; F.S. Mohd Taib: Contributed in statistical analysis, M.N. Shukor: Project Leader; M.H. Shahril and E.A. Filza: Representatives of TNB Research (TNBR) for Research Fund.

Research content : The research content of manuscript is original and has not been published elsewhere.

Ethical approval : NotApplicable

Conflict of interest : The authors declare that there is no conflict of interest.

\section{Data from other sources : NotApplicable}

Consent to publish : All authors agree to publish the paper in Journal of Environmental Biology.

\section{References}

Addo-Fordjour, P., Z.B. Rahmad and A.M. Shahrul: Environmental factors influencing liana community diversity, structure and habitat associations in a tropical hill forest, Malaysia. Plant Ecol Divers., 7 , 485-496 (2014).

Avery, B.W. and C.L. Bascomb: Soil Survey Laboratory Methods. Soil Survey Technical Monograph No. 6, Rothamsted Experimental Station, Lawes Agricultural Trust, Harpenden (1982).

Chettri, A., S.K. Barik, H.N. Pandey and M.K. Lyngdoh: Liana diversity and abundance as related to microenvironment in three forest types located in different elevational ranges of the Eastern Himalayas. PlantEcol. Divers., 3, 175-185 (2010).

DeWalt, S.J., K. Ickes, R. Nilus, K.E. Harms and D.F.R.P. Burslem: Liana habitat associations and community structure in a Bornean lowland tropical forest. Plant Ecol., 186, 203-216 (2006).

Esu, I.E.: Detailed Soil Survey of NIHORT Farm at Bunkure, Kano State, Nigeria. Institute for Agricultural Research, Ahmadu Bello University, Zaria (1991).

Farah Khaliz, K., H. Zulhazman, S. Nur Sayzwani, Y. Siti Hajar, A.M. Nur Kyariatul Syafinie, M. Nasihah and A. Siti Fatimah: Distribution and ecology of Rafflesia in Royal Belum State Park, Perak, Malaysia. Int. J. Eng. Technol., 7, 292-296 (2018).

Friesen, D.K., A.S.R. Juo and M.H. Miller: Liming and lime phosphoruszinc interactions in the soils. Soil Sci. Soc. Am. J., 44, 1221-1226 (1980).

Frossard, E., L.M. Conron, A. Oberson, S. Sinaj and J.C. Fardeau: Processes governing phosphorus availability in temperate soils. J. Environ. Qual., 29, 15-23 (2000).

Gentry, A.H.: The distribution and evolution of climbing plants. In: The Biology of Vines. (Eds.: F.E. Putz and H.A. Mooney). Cambridge University Press, Cambridge, UK, pp.3-49 (1991).

Homeier, J., F. Englert, C. Leuschner, P. Weigelt and M. Unger: Factors controlling the abundance of lianas along an altitudinal transect of tropical forests in Ecuador. For. Ecol. Manag., 259, 1399-1405 (2010).

Ibarra-Manríquez, G. and M. Martínez-Ramos: Landscape variation of liana communities in a Neotropical rain forest. Plant Ecol., 160, 91-
112 (2002).

Khairil, M., W.A. Wan Juliana, M.S. Nizam and W.M. Razi Idris: Soil properties and variation between three forest types in tropical watershed forest of Chini Lake, Peninsular Malaysia. Sains Malays., 43, 1635-1643 (2014).

Landon. J.R.: Bookers Tropical Soil Manual. Longman, Hong Kong (1991).

Laurance, W.F., D. Perez-Salicrup, P. Delamonica, P.M. Fearnside, S. D'Angelo, A. Jerozolinski, L. Pohl and T.E. Lovejoy: Rainforest fragmentation and the structure of Amazonian liana communities. Ecology, 82, 105-116 (2001).

Malizia, A., H.R. Grau and J.W. Lichstein: Soil phosphorus and disturbance influence liana communities in a subtropical montane forest. J. Veg. Sci., 21, 551-560 (2010).

McCauley, A., C. Jones and K. Olson-Rutz: Nutrient Management Module No. 8: Soil pH and Organic Matter. Montana State University, Montana (2017).

Metson, A.J.: Methods of Chemical Analysis for Soil Survey Samples. New Zealand Department of Scientific and Industrial Research, Wellington, New Zealand (1956).

Nais, J.: Rafflesia of the World. Sabah Parks in association with Natural History Publications (Borneo) Sdn.Bhd., Kota Kinabalu, Malaysia (2001).

Nasihah, M., H. Zulhazman, M.Y. Siti Munirah, W.A. Wan Norqayyum Nadia and A. Latiff: Tetrastigma hookeri (Laws.) Planch. (Vitaceae), a host plant for Rafflesia kerrii Meijer in Peninsular Malaysia. Malayan Nat. J., 68, 33-39 (2016).

Nur Hayati, A.K., K. Shamsul, W.A. Wan Juliana, M.H. Shahril, E. Alyaa Filza and $\mathrm{H}$. Mohamed Shah Redza: Reassessment of the Rafflesia populations and habitats in Royal Belum State Park, Perak, Peninsular Malaysia. Malayan Nat. J., 71, 493-498 (2020).

Osman, K.T.: Forest Soils - Physical Properties of Forest Soils. Springer International Publishing, Switzerland, pp. 19-44 (2013).

Othman, Y. and J. Shamsuddin: Sains Tanah. Dewan Bahasa dan Pustaka, Kuala Lumpur (1982).

Pranata, S., S. Sulistijorini and T. Chikmawati: Ecology of Rafflesia arnoldii (Rafflesiaceae) in Pandam Gadang West Sumatra. J. Trop. Life Sci., 9, 243-252 (2019).

Schnitzer, S.A.: A mechanistic explanation for global patterns of liana abundance and distribution. Am. Nat., 166, 262-276 (2005).

Schoeneberger, P.J., D.A. Wysocki, E.C. Benham and W.D. Broderson: Field Book for Describing and Sampling Soils: Version 2.0. National Soil Survey Center, Natural Resources Conservation Services. US Department of Agriculture Lincoln, Nebraska (2002).

Shamshuddin, J.:Asas Sains Tanah. Dewan Bahasa dan Pustaka, Kuala Lumpur (1981)

Sharu, M.B., M. Yakubu, S.S. Noma and A.I. Tsafe: Characterisation and classification of soils on an agricultural landscape in Dingyadi District, Sokoto State, Nigeria. Nig. J. Basic Appl. Sci., 21, 137-147 (2013).

Smith, J.L. and J.W. Doran: Measurement and use of $\mathrm{pH}$ and electrical conductivity for soil quality analysis. In: Methods for assessing soil quality (Eds.: J.W. Doran and A.J. Jones). Vol. 49, Soil Science Society of America, Madison, WI, pp. 169-185 (1996).

Swaine, M.D. and J. Grace: Lianas may be favoured by low rainfall: Evidence from Ghana. Plant Ecol., 192, 271-276 (2007).

USDA.: Soil Classification. A Comprehensive System. $7^{\text {th }}$ Approximation. US Department of Agriculture, Washington D.C., USA(1960). 